\title{
Development of Modern Primary Education in Variativity Conditions
}

\section{Nesterenko}

Berdyansk State Pedagogical University

Paper received 13.06.18; Accepted for publication 21.06.18.

https://doi.org/10.31174/SEND-PP2018-173VI71-07

\begin{abstract}
Theoretical aspects of the functioning of primary education at the present stage in conditions of its variativity are highlighted in the article. The content of the concept of «variativity» is researched, the ideas of contemporary scholars about the essence of this principle are highlighted, and the relevance of upgrading the training of future teachers to modeling the lessons under the specified conditions is substantiated.
\end{abstract}

Keywords: primary education, principle, variativity, conditions, vocational training of future teachers of primary school.

Formulation of the problem. Socio-cultural transformations of Ukrainian society and reorganization of education are aimed at preparing the personality of a junior pupil to life, where the development of his abilities and the formation of key competencies is a priority. In order to meet the challenge of time, elementary school must respond quickly to innovative changes that are realized in the possibility of obtaining education in institutions of various types, modernizing of its content, creating a new generation of standards and qualitatively other teaching and methodological support; organization of comfortable educational space, active introduction of modern pedagogical technologies, etc. Therefore, current legal documents (Law of Ukraine «On Education» (2017), the Draft Concept for the Development of Education of Ukraine for the period 2015-2025 (2014), the Concept of the New Ukrainian School (2017), the State Standard for Primary Secondary Education (2018), etc. ) certify the right of the modern primary school to function in conditions of variativity, which opens access to quality education for students and gives their parents the freedom to choose an educational institution with certain programs and conditions of existence in accordance with the individual abilities and interests of children, and teachers - space for professional work.

Analysis of recent research and publications. The term «variativity» is interpreted in scientific sources as «the presence of variations, the possibility of variation» or «modification, which is implemented through options» (Interactive Dictionary of the Ukrainian language); «the presence of modification in speech, caused by different conditions for the use of linguistic units, as well as the difference in the membership of speakers in the social or territorial environment» (Dictionary of linguistic terms); the mechanism of implementation of the principle of individualization, which provides students with a choice of various high-quality, specific and attractive variants of educational trajectories (Glossary of Modern Education).

The essence of the principle of variativity in education is considered in various ways in the pedagogical researches by O. Antonova, S. Vitvytska, K. Hnezdilova, O. Dubaseniuk, V. Kyzenko, V. Kovalchuk, M. Matishak, N. Sydorchuk, O. Spirin, L. Khoruzha and others. Thus, L. Khoruzha reveals the notion of variativity, opposing it to invariance, and in the development of the personality the second is the foundation for the first. The scientist considers the strategy of education reform to be a variativity based on the teacher's ability to use various technologies that support the processes of his self- improvement and self-realization, recognizing the universal human values and ethical norms of behavior as priorities. This encourages the active implementation of existing and independent search for new educational resources [11].

Considering the essence of pedagogical activity as a dynamic system of interaction between subjects of the educational process, O. Dubaseniuk «variativity» (realization of the tendency towards a change of the achieved for its purposeful improvement) opposes to «normativity» (preservation of all useful, acquired in educational activity) $[8$, p. 177].

In the functioning of pedagogical systems, variativity is considered by V. Kovalchuk as uniqueness, originality in the conditions of a particular educational institution, where opportunities for the formation and development of a harmoniously developed personality and the existence of a developing environment in accordance with regional needs are recognized [4, p. 68-136].

V. Kyzenko considers the variational component of the content of education as the main one for the realization of the personality-oriented approach, which determines and ensures in a particular educational institution the orientation towards satisfying the cognitive needs of students with different degrees of motivation, interests, the speed of perception of educational material, etc. Variativity is aimed at personal growth of each person and gives an opportunity to consciously and purposefully choose content in accordance with individual needs and requirements, which provides an increase in the level of knowledge [2].

As we see, the relationship of variativity with the individualization of learning provides the possibility of creating a certain trajectory of learning, the choice of forms and methods during educational activities in accordance with natural instincts, the needs of the personality and promotes the development of giftedness, which greatly increases the interest in the peculiarities of the implementation of this principle in primary education.

The purpose of the article is to reveal the theoretical aspects of the formation of primary education at the present stage in conditions of its variativity.

Presentation of the main material. The problems of the development of primary education in the conditions of variativity are highlighted in the works by N. Bibik, Ya. Haievets, O. Kazanicher, L. Koval, V. Martynenko, T. Miier, M. Ovchynnikova, Z. Onyshkiv, O. Onopriienko, K. Ponomarova, O. Savchenko, S. Skortsova, L. Khoruzha, A. Tsymbalaru and others. In 
particular, academician O. Savchenko emphasizes the use of author's programs, alternative textbooks, manuals with various methodological approaches to the implementation of content lines, the existence of manuals and workbooks on the one subject, which allows the lessons to be more dynamic, interesting in terms of content [9].

Observance of the principle of variativity, according to the scientist, subject to the introduction of a competenceoriented approach involves a special educational interaction within a particular class, which is constantly modernized in order to achieve developmental influence on junior pupils, the formation of their reading skills, writing skills, communication skills, digital thinking, etc. [1].

Z. Onyshkiv, investigating the activity of the primary school teacher at secondary schools in rural areas, argues that variativity depends on the peculiarities of each lesson and the organization of the educational process in general. The scientist highlights the following types of the existence of general education institutions of the 1st degree: primary school, where each classroom is taught by a separate teacher; a small primary school, which combines classes of small fullness or sets of classes; educational complex «elementary school - kindergarten», «school family», in which there is a small number of classes, etc. [7, p. 209].

M. Matishak tried to establish the connection between variativity and differentiated learning, considering them to be democratic principles of restructuring modern Ukrainian primary education, which consist in the choice of organizational forms of educational activity for pupils aged 6-7 years [5].

Among the didactic principles of the organization of learning and research activities for junior pupils, T. Miier calls integration, which is characterized by a variational representation of the content and awareness of various ways of its implementation as a result of internalization of social experience on the basis of knowledge of fundamental educational objects [6].

According to L. Koval, an important quality of a modern primary school is the technological variativity in the organization of educational activities of junior pupils. After all, to ensure that each lesson gives the student a personal acquisition in the form of competences, it is important to use fully the opportunities of educational and game technologies, among which the scientist names the following: cooperation between teachers and students; formation of general educational skills and abilities of junior schoolchildren; organization of educational project activities; gradual assimilation of the educational material by the pupils. In addition, the introduction of the technological approach, according to L. Koval, involves the design of educational process, which is based on the ability of each student to select the content of the activity according to his motivation, individual preferences, abilities to achieve a situation of success [3].

S. Skvortsov introduces the notion of «variable competence of the primary school teacher», interpreting it as a willingness to work on any teaching set; the ability to choose between them the most effective one for achieving the goals and objectives of learning a particular subject defined by the State Standard of Elementary Education and the relevant curriculum [10].
The modernization of the primary school, according to A. Tsymbalaru, is made by designing the educational space within the limits of a certain organizational form (lesson, excursion, individual classes, etc.) - a sociocultural educational situation, during which a choice of interaction can be made taking into account the individual psychological characteristics of junior pupils, namely, the dominant channel of perception of information (audio, visual or kinestic); the features of the processing of educational information (analytical or synthetic); the leading style of educational activity (naturalistic, musicalrhythmic, verbal-linguistic, logic-mathematical, motormobile); a comfortable type of communication (introvert, extrovert), etc. [12, p. 306-307].

Special importance in the creation of the primary school educational space A. Tsymbalaru gives to the variational approach to the arrangement of furniture in the classroom, which will allow students to work independently or in pairs, sitting (at a desk between zones 2 and 3) or standing (at a table or desk between zones 1 and 3 ), as well as face to face with the teacher (zone 4), and will let teachers take into account the state of each child (fatigue, bad mood or well-being), store her attention and performance by changing the posture, the type and objects of interacting, the renewal of the group, including quantitative renewal [1].

Revealing the theoretical aspects of the functioning of primary education at the present stage it is important to clarify the possibilities of modeling lessons in conditions of their variativity. This problem is covered in the works by O. Savchenko, N. Bibik, A. Tsymbalaru, V. Martynenko, K. Ponomarova, O. Onopriienko, N. Lystopad and others.

The core of modeling a separate lesson and their system on the basis of variativity, according to O. Savchenko, should be the mutual agreement of the goal and the expected result. At the same time, it is necessary to determine the enlarged result of training (competence), which can not be achieved within 2-3 lessons. Competence is formed and developed for a long time, therefore it is necessary to orientate in the sequence of the objectives of studying the subject in the State Standard and the curriculum, which specifies in each content line the requirements for the level of general education of junior schoolchildren by grade.

Considering the variativity of the forms of the organization of educational and cognitive activity of junior schoolchildren in the lessons of the Ukrainian language, $\mathrm{K}$. Ponomareva focuses on modeling and conducting nonstandard classes: lesson-research, lesson-fairy tale, lessonexcursion, lesson-competition, lesson-presentation of the project, lesson of development verbal creative abilities, etc. In her opinion, this will activate younger schoolchildren to foresee risks, make decisions in atypical situations; support interest in learning, encourage the initiative, promote the formation of skills of interaction with other participants of the educational process. All this ensures the development of a person who has a sufficient level of culture, a knowledge of the fundamentals of the sciences, is able to think creatively, take initiative, creatively solve vital problems, and so on. [1, p. 106-134].

The variativity of the structure of the lesson from the course «I am in the world», according to N. Bibik, should 
be dynamic, flexible, and give the opportunity for teachers to react quickly in various learning situations. The modeling of such lessons provides for a non-standard ratio of frontal, group and individual forms of work, so that younger schoolchildren learn the material in dynamics, from the previously learned to the new [1, p. 176199].

When modeling the lesson in literary reading in primary school, V. Martynenko proves that there must be an obligatory component (the teaching material provided by the program) and the creativity of the teacher, which is based on the variativity of the creation of learning situations in accordance with the individual psychological characteristics of pupils and improvisation as reaction to the reader's impressions of children. The essence of the creative modeling of the literary reading lesson is to select, in accordance with the specifics of the text of the work, appropriate methods and techniques for its assimilation (communication with the text, the book, the author of the work, creative reading, solving creative tasks; heuristic, research methods, etc.), aimed at developing the creative imagination, the emotional-sensual sphere of pupils [1, p. 134-159].

The principle of variativity, according to O. Onopriienko, should be actively applied by the teacher of the primary school during the monitoring and evaluating activities of pupils. Among them, the researcher identifies the following types: quantitative-criterial (knowledge, skills), individual (personal account of the real achievements of each pupil), meaningful (evaluation without scoring), rating (compensatory means of nonevaluation) and formative (systematic tracking of individual progress of pupils in the learning process). The variativity of the choice of the control means by the teacher depends on the predicted model of the lesson and the corresponding criteria defined in the State Standard. The result of the teacher's monitoring and evaluation activity in the system of lessons encourages younger pupils to have high academic achievements; allows designing of individual educational route; contributes to the creation of a positive microclimate, a situation of success, emotional satisfaction; attracts pupils to the use of reflexive skills (self-analysis, self-control, self-evaluation, selfcorrection), focuses on the development of new skills and personal qualities [1, p. 200-217].

So, studying the problem of the functioning of modern primary education in conditions of variativity, it should be noted that this process implies the possibility of training in institutions of various types; updating content (using author programs, alternative textbooks, manuals and workbooks); maintaning comfortable educational space; active introduction of innovative pedagogical technologies; various kinds of control and evaluation activity of the results of the education of junior schoolchildren. Summarizing the features of modeling lessons in primary school, taking into account the variativity of organizational forms and methods of teaching, it should be noted that they will create an educational space for junior schoolchildren which will qualitatively prepare them for lifelong learning.

Prospects for further research. A detailed review of the problem, investigated in the article, indicates the relevance of making adjustments to the content of the training of future teachers in order to ensure the organization of the primary school educational space in conditions of its variativity. This will be the subject of our further scientific search.

\section{ЛІТЕРАТУРА}

1. Варіативність організаційних форм компетентнісно орієнтованого навчання у початковій школі : монографія [О. Я. Савченко, Н. М. Бібік, А. Д. Цимбалару, В. О. Мартиненко, К. І. Пономарьова, О.В.Онопрієнко, Н. П. Листопад], під наук. ред. О. Я. Савченко. - К. : Педагогічна думка, 2016. - 283 с.

2. Кизенко В.I. Варіативний компонент змісту освіти в старшій школі : посіб. для вчителів, керівників загальноосвіт. навч. закл., працівників органів освіти, аспірантів і студентів / Василь Іванович Кизенко. - К. Педагогічна думка, 2007. - 133 с.

3. Коваль Л.В. Сучасні навчальні технології в початковій школі : навч.-метод. посіб. / Людмила Коваль. Донецьк : ТОВ «Юго-Восток, Лтд», 2006. - 225 с.

4. Ковальчук В.А. Теоретичні та методичні основи професійної підготовки майбутніх учителів до роботи в умовах варіативності освітньо-виховних систем : дис. ... докт. пед. наук : 13.00.04 / Валентина Антонівна Ковальчук ; Житомирський державний університет імені Івана Франка. - Житомир, 2016. - 514 с.

5. Матішак М.В. Варіативність організаційних форм навчальної діяльності учнів 6-7-річного віку: автореф. дис... канд. пед. наук: 13.00.09 / Маріанна Василівна Матішак; Національний педагогічний ун-т ім. М. П. Драгоманова. - К., 2008. - 20 с.

6. Miєp T.I. Дидактичні засади організації навчальнодослідницької діяльності молодших школярів : дис. ... докт. пед. наук : 13.00.04 / Тетяна Іванівна Мiєр; Національна академія педагогічних наук України. - К., 2017. $-594 \mathrm{c}$.

7. Онишків 3.М. Система підготовки майбутніх учителів початкових класів до роботи в загальноосвітніх навчальних закладах сільської місцевості : дис. ... докт. пед. наук : 13.00.04 / Зиновій Михайлович Онишків; Тернопільський національний педагогічний університет імені Володимира Гнатюка. - Тернопіль, 2016. - 439 с.

8. Професійна педагогічна освіта : акме-синергетичний підхід : монографія / за ред. О. А. Дубасенюк. Житомир : Вид-во ЖДУ ім. І. Франка, 2011. - 389 с.

9. Савченко О.Я. Якість і варіативність шкільних підручників як умова запровадження державних стандартів початкової освіти // Початкова школа. - 2001. - № 8. - С. 10-12.

10. Скворцова С.О. Підготовка майбутніх учителів початкових класів до навчання молодших школярів розв'язувати сюжетні математичні задачі : монографія / С. О. Скворцова, Я. С. Гаєвець. - Х. : Ранок-НТ, 2013. $332 \mathrm{c}$.

11. Хоружа Л. Інваріантність та варіативність професійної діяльності викладача вищої школи в епоху змін / Л. Л. Хоружа / Теорія та методика професійнопедагогічної підготовки освітянських кадрів акмеологічні аспекти : монографія / керівн. авт. кол. Н. В. Гузій; Мінво освіти і науки України, Нац. пед. ун-т імені М. П. Драгоманова. - Київ: Вид-во НПУ імені М. П. Драгоманова, 2018. - 516 с.

12. Цимбалару А.Д. Педагогічне проектування освітнього простору в школі I ступеня : теорія $\mathrm{i}$ практика : монографія / Анжеліка Дмитрівна Цимбалару. - К. : Педагогічна думка, 2013. - 692 с. 


\section{REFERENCES}

1. The variativity of organizational forms of competencyoriented learning in elementary school : monograph / [O. Ya. Savchenko, N. M. Bibik, A. D. Tsymbalar, V. O. Martynenko, K. I. Ponomarova, O. V. Onopriienko, N. P. Lystopad], ed. O. Ya. Savchenko. - K. : Pedahohichna dumka, 2016. $283 \mathrm{p}$.

2. Variative component of the content of education in high school: manual for teachers, heads of the general educational institutions, educational workers, students and postgraduate students / Vasyl Ivanovych Kyzenko. - K. : Pedahohichna dumka, 2007. $-133 \mathrm{p}$.

3. Koval L.V. Modern teaching technologies in elementary school : teaching methodical manual / Liudmyla Koval. Donetsk : TOV «Iuho-Vostok, Ltd», 2006. - 225 p.

4. Kovalchuk V.A. Theoretical and methodical foundations of the professional training of future teachers for work in conditions of variativity of educational systems : Ph.D. dissertation : 13.00.04 / Valentyna Antonivna Kovalchuk ; Zhytomyr Ivan Franko State University. - Zhytomyr, 2016. - 514 p.

5. Matishak M.V. The variativity of organizational forms of educational activity for pupils aged 6-7 years : abstract of Ph.D. dissertation: 13.00.09 / Marianna Vasylivna Matishak; National Pedagogical Dragomanov University. - K., 2008. $20 \mathrm{p}$.

6. Miier T.I. Didactic principles of organization of teaching and research activity of junior pupils: Ph.D. dissertation : 13.00.04 / Tetiana Ivanivna Miier; National Academy of Educational Sciences of Ukraine. - K., 2017. - 594 p.

7. Onyshkiv Z.M. System of preparation of future teachers of elementary school for work in rural educational establishments : Ph.D. dissertation : 13.00.04 / Zynovii Mykhailovych Onyshkiv; Ternopil Volodymyr Hnatiuk National Pedagogical University. - Ternopil, 2016. - 439 p.

8. Professional teaching education: acme-synergetic approach : monograph / ed. O. A. Dubaseniuk. - Zhytomyr : Zhytomyr Ivan Franko State University Publication, 2011. - 389 p.

9. Savchenko O. Ya. The quality and variability of school textbooks as a condition for the introduction of state standards for elementary education // Pochatkova shkola. - 2001. - № 8. P. 10-12.

10. Skvortsova S.O. Preparation of future primary school teachers for teaching junior pupils to solve thematic mathematical problems : monograph / S.O. Skvortsova, Ya. S. Haievets. Kh. : Ranok-NT, 2013. -332 p.

11. Khoruzha L. Invariance and variativity of the professional activity of the teacher of high school in the era of changes / L. L. Khoruzha / Theory and methodology of vocational and pedagogical training of educational personnel : akmeological aspects : monograph / ed. N.V. Huzii ; Ministry of Education and Science of Ukraine, National Pedagogical Dragomanov University. - Kyiv : National Pedagogical Dragomanov University Publication, 2018. $-516 \mathrm{p}$.

12. Tsymbalaru A.D. Pedagogical design of educational space at I degree school : theory and practice : monograph / Anzhelika Dmytrivna Tsymbalaru. - K. : Pedahohichna dumka, 2013. $692 \mathrm{p}$. 